0278-5846(94)00095-6

\title{
SELECTIVE INHIBITION BY ALCOHOL AND CORTISOL OF NATURAL KILLER CELL ACTIVITY OF LYMPHOCYTES FROM CORD BLOOD
}

\author{
MADHAVAN P.N. NAIR *, ZAID \\ A. KRONFOL + , JOHN F. GREDEN ${ }^{+}$, \\ KAILASH C. CHADHA **,UMAKANT J. DUMASWALA ${ }^{++}$, \\ ANN M. SWEET ${ }^{*}$ AND STANLEY A. SCIIWARTZ * \\ *Dept of Medicine, SUNYAB, Buffalo, NY USA \\ +Dept of Psychiatry and Alcohol Research Center, University of \\ Michigan, Ann Arbor, MI USA \\ **Dept of Cellular and Molecular Biology, Roswell Park Cancer \\ Institute, Buffalo, NY USA \\ ${ }^{++}$Hoxworth Blood Center, University of Cincinnati, Cincinnati, OH USA
}

(Final form, August, 1993)

\begin{abstract}
$\underline{\text { Abstract }}$
Nair, Madhavan P.N., Kronfol, Zaid A., Greden, John F., Chadha, Kailash C., Dumaswala, Umakant J., Sweet, Ann M., and Schwartz, Stanley A.: Selective Inhibition by Alcohol and Cortisol of Natural Killer Cell Activity of Lymphocytes from Cord Blood. Prog. Neuro. Psycho-pharmacol. \& Biol. Psychiol. 1994, 18(8): 1293-1305.
\end{abstract}

1. The immunosuppressive effects of drugs such as alcohol or hormones such as cortisol may be age-related. To test this hypothesis, the authors investigated the in vitro effects of ethanol (EtOH) and cortisol on Natural Killer (NK) cell activity of lymphocytes from normal cord blood in comparison with that of lymphocytes from normal adult peripheral blood.

2. K562, an erythroleukemia cell line, was used as a target in a $4 \mathrm{hr} 51 \mathrm{Cr}$ release assay. 3. Ethanol at $0.3 \%(\mathrm{~V} / \mathrm{V})$ and cortisol at $0.05,0.1$ and $0.2 \mu \mathrm{g} / \mathrm{ml}$ concentrations, added directly to a mixture of effector and target cells significantly suppressed the NK activity of cord blood lymphocytes in a dose dependent fashion, whereas similar concentrations of either EtOH or cortisol did not manifest significant immunoregulatory effects on NK cell activity of normal adult lymphocytes.

4. Pre-treatment of the target with either EtOH or cortisol for 4 hours did not affect cytotoxicity. Inhibition of cytotoxicity was also not due to direct toxicity of effector cells because lymphocytes treated with either $\mathrm{EtOH}$ or cortisol showed normal $51 \mathrm{Cr}$ release and their viability was comparable to that of untreated control cells.

5. This suggests a selective inhibitory effect of EtOH and cortisol on NK activity of neonatal lymphocytes that may be of clinical significance. 
Kevwords: alcohol. cortisol. natural killer. lymphocytes

Abbreviations: adult peripheral blood lymphocyte (aPBL), antibody dependent cellular cytotoxicity (ADCC), cord blood lymphocytes (CBL), ethanol (EtOH), hypothalamic pituitary adrenal (HPA) Hanks' balanced salt solution (HBSS), herpes simplex virus (HSV), lymphokine activated killer (LAK), natural killer (NK), Roswell Park Memorial Institute (RPMI)

\section{Introduction}

Previous studies suggest that a bidirectional communication network exists between the central nervous system and the immune system which is primarily mediated through shared neuropeptide signals produced in response to the activation of the hypothalamic-pituitary adrenal (HPA) axis (Bateman et al, 1989; Stein et al, 1988; Biondi \& Kotzzlidis, 1990; Dunn, 1989). It is now becoming clear that lymphocytes not only synthesize and secrete neuropeptides and hormones; they possess receptors for these neuro-endocrine molecules (Solomon 1985). Glucocorticoids are the end products of endocrine-immune interactions. Negative feedback regulation by cortisol on the production of neuropeptides and hormones by activated HPA axis and the immune system has also been reported Bateman et al, 1989). Natural killer (NK) and antibody dependent cellular cytotoxic (ADCC) activities are considered as the body's early defense mechanisms against viral infection and tumors (Herberman \& Holden, 1978; Welch, 1981). Previous studies have demonstrated that glucocorticoids exent significant downregulation of various immune responses including NK, (Nair \& Schwartz, 1984, 1988), polyclonal B cell activation (Yu et al, 1974) and cytokine production (Wahl et al, 1975).

Chronic alcohol consumption is associated with abnormalities of humoral (Drew et al, 1984; Delacroix et al, 1982; Morgan et al, 1980; and Chang et al, 1990) and cellular immunity (Jerrells et al, 1989; Meadows et al, 1992; Ericsson et al, 1980; Watson et al, 1984; Hodgson et al, 1978) including dysfunction of suppressor (Woltjen et al, 1980; Kawanashi et al, 1981), helper (McKeever et al, 1988) and cytotoxic lymphocyte activities (Abdallah et al, 1983; Saxena et al, 1980; Meadows et al, 1989) as well as production of soluble immune mediators (Nair et al, 1993). Considerable evidence suggests an association between alcohol consumption, increased risk of cancer and possible involvement of NK cell activity (Yirmiya et al, 1992). Alcohol consumption is also known to activate the HPA axis resulting in the release of neurohormone or neuropeptides (Redei et al, 1986, 1988; Gottesfeld et al, 1990; Jerrells et al, 1989) which in turn is known to have profound effects on immune functions (Fauci, 1978) and tumor growth (Riely, 1981). The atuthors have previously reported that lymphocytes from nonalcoholic, healthy donors precultured in vitro with different concentrations of 
alcohol manifest decreased levels of NK, ADCC and lymphokine activated killer (LAK) cell-activities (Nair et al, 1990). The authors have also shown that patients with depression, demonstrating high levels of cortisol, manifested significantly decreased levels of NK activity (Kronfol et al, 1990).

A decline of various immunological functions with age has been suggested (Miller, 1991). Neonates are known to have increased susceptibility to disseminated and devastating infections (Schaffer and Avery, 1971). The ability of cord blood lymphocytes (CBL) to mediate $\mathrm{NK}$ and $\mathrm{ADCC}$ activities has been reported, but with conflicting findings ( Kohl et al, 1981; Antovelli et al, 1981; Kaplan et al, 1982; Hashimoto et al, 1983; Uksila et al, 1982; Tarkkanen et al, 1982). In a mouse model, age related changes in alcohol induced immunosuppression were also reported (Saad and Jerrells, 1990; Makinoden et al, 1987). These studies suggest that alcohol and age can interact to produce specific changes in the regulation of various immune functions. However, the effect of alcohol, and cortisol on immune functions of lymphocytes has not been clearly elucidated with respect to aging. In the present investigation, the authors examined the direct effect of cortisol and alcohol on NK activity of cord blood lymphocytes in comparison to adult peripheral lymphocytes.

\section{Methods}

\section{Preparation of Effector Cells}

Neonatal umbilical cord blood samples were collected in heparinized $(20 \mathrm{U} / \mathrm{ml})$ tubes under sterile conditions from healthy term infants at vaginal delivery before the expulsion of the placenta. Heparinized $(20 \mathrm{U} / \mathrm{ml})$ peripheral blood was obtained simultaneously from healthy unrelated adult volunteers of either sex $(20$ to 40 years of age). Blood samples were processed immediately after collection. Donors or their parents were apprised of the study and consents were obtained consistent with the policies of the NIH. Mononuclear cells from both adult and cord blood samples were isolated using a modified method of Boyum (Boyum, 1968). Blood was diluted with an equal volume of $\mathrm{Ca}^{2+}$ and $\mathrm{Mg}^{2+}$-free Hanks' balanced salt solution [HBSS (GIBCO, Grand Island, N.Y.)] and centrifuged at $400 \mathrm{x} \mathrm{g}$ for $30 \mathrm{~min}$ at $18^{\circ} \mathrm{C}$ over a cushion of FicollHypaque (Pharmacia Fine Chemicals, Piscataway, N.J.). The mononuclear cell band was harvested, washed three times with HBSS, and resuspended in RPMI 1640 medium containing $25 \mathrm{mM}$ Hepes buffer supplemented with $10 \%$ heat-inactivated fetal bovine serum [FBS (GIBCO), $80 \mathrm{ug} / \mathrm{ml}$ gentamicin (Schering Corp., Kenilworth, N.J.), and $300 \mathrm{ug}$ fresh glutamine/ml (complete medium). 


\section{Depletion of Adherent Cells}

Mononuclear cells were depleted of adherent cells as described (Nair and Schwartz, 1983). Briefly, total mononuclear cells were suspended in RPMI 1640 with $10 \%$ FBS and passaged through a $7 \mathrm{ml}$ column of Sephadex G-10 beads (Pharmacia) equilibrated in the same medium. After 45 min of incubation at $37^{\circ} \mathrm{C}$, nonadherent cells were washed through with 1 bed vol of warm $\left(37^{\circ} \mathrm{C}\right)$ medium. The cell recovery was $>70 \%$ of the total input, and monocyte contamination was $<2 \%$ as indicated by nonspecific esterase staining.

\section{Preparation of Target Cells}

Mycoplasma-free human erythroleukemic cell line, K-562, was used as target for NK cells in a $4 \mathrm{hr} 5 \mathrm{l} \mathrm{Cr}$ release assay. Tumor target cells were serially passaged in complete medium and used in cytotoxicity assays no more than $48 \mathrm{hr}$ after the last passage. 200 $\mu \mathrm{Ci}$ of ${ }^{51} \mathrm{Cr}$ as sodium chromate (New England Nuclear, Boston, MA) was added to $0.8 \mathrm{ml}$ aliquots of complete medium containing $5 \times 10^{6}$ washed tumor cells. The cells were incubated at $37^{\circ} \mathrm{C}$ for $1 \mathrm{hr}$ in a humidified atmosphere of $5 \% \mathrm{CO}_{2}$, with intermittent shaking. After incubation, the cells were washed three times with complete medium and resuspended at a concentration of $1 \times 10^{5}$ cells $/ \mathrm{ml}$.

\section{Assasy for NK Cell Activity}

NK cell activity was measured in a direct $5 \mathrm{l} C \mathrm{Cr}$ release assay as previously described (Nair et al, 1990). A fixed number of effector cells in complete medium was added to triplicate cultures of $51 \mathrm{Cr}$-labeled target cells in a $V$-bottom microtitration plates (CoStar, Cambridge, MA). After centrifugation at $40 \times \mathrm{g}$ for $10 \mathrm{~min}, 100 \mu \mathrm{l}$ aliquots were removed from each well and transferred to glass tubes and read in a Packard Model 593 gamma counter. Percentage cytotoxicity was calculated as follows:

$$
\% \text { cytotoxicity }=\frac{\text { experimental release }- \text { spontaneous release }}{\text { total release }- \text { spontaneous release }} \times 100
$$

Spontaneous release represents counts released from control wells containing only $1 \mathrm{X}$ $10^{4}$ target cells, and total release represents counts obtained from an aliquot of $1 \times 10^{4}$ target cells. 


\section{Data Analysis}

The data were analyzed by the student " $t$ " test and the significance of differences in the mean values between control and treated groups were considered significant at $P<.05$ levels.

\section{$\underline{\text { Results }}$}

Data presented in Table 1 demonstrate the in vitro effects of alcohol on NK activity of cord blood lymphocyte (CBL) compared to adult peripheral blood lymphocyte (a-PBL). CBL depleted of adherent cells demonstrated significantly $(\mathrm{p}<0.001)$ lower level of NK activity (14.8\%) compared to a-PBL $(26.7 \%)$ at $25: 1$ effector to target (E:T) cell ratio. CBL also demonstrated significant suppression of NK activity at other E:T cell ratios of 100:1, 50:1 and 10:1 compared to a-PBL (data not presented). Direct addition of alcohol at concentrations of $0.1,0.2$ and $0.3 \%$ to the reaction mixture of a-PBL and target cells did not produce any effect on NK activity; the percent cytotoxicities being $24.5,23.8$ and $21.4 \%$ respectively compared to $26.7 \%$ manifested by control a-PBL. Alcohol at $0.1,0.2$ and $0.3 \%$ manifested a dose dependent inhibition of NK activity of CBL; the percent cytotoxicities being $10.3,8.4$ and 7.2 respectively compared to $14.8 \%$ produced by control CBL. Alcohol at higher a concentration $(0.3 \%)$ produced statistically significant $(\mathrm{p}<.02)$ suppression of NK activity of CBL.

Since cortisol is known to affect the immune responses of adult lymphocytes, in general, and infants born by vaginal delivery also demonstrate higher blood cortisol levels (Gaspasoni et al, 1991); we examined the direct effect of cortisol on NK activity of CBL. The data presented in Table 2 show that cortisol at concentrations, $0.05,0.1$ and $0.2 \mu \mathrm{g} / \mathrm{ml}$ added directly to the reaction mixture of a-PBL and target cells did not produce any significant inhibitory effects; the cytotoxicities being $24.3,21.4$ and $22.7 \%$ respectively compared to $25 \%$ cytotoxicity produced by untreated control cultures. However, cortisol at similar concentrations produced significant inhibitory effect on the NK activity of CBL; the cytotoxicities being $8.5(p<0.05), 6.6(p<0.01)$ and $6.5 \%(p<0.005)$ respectively at $0.05,0.1$ and $0.2 \mathrm{ug} / \mathrm{ml}$, compared to $14.8 \%$ manifested by untreated control CBL. These results suggest that cortisol produces a selective inhibitory effect on NK activity of CBL. 
Effect of Direct Addition of Alcohol on NK Activity of Lymphocytes

\begin{tabular}{clc}
\hline \multirow{2}{*}{ Effector Source } & $\begin{array}{c}\text { Concentration of } \\
\text { Alcohol (\%) }\end{array}$ & \% Cytotoxicity \\
\hline \multirow{2}{*}{ aPBL } & 0 & $26.7 \pm 2.5$ \\
& 0.10 & $24.5 \pm 2.2(\mathrm{NS})$ \\
& 0.2 & $23.8 \pm 0.8(\mathrm{NS})$ \\
& 0.3 & $21.4 \pm 2.5(\mathrm{NS})$ \\
$\mathrm{CBL}$ & 0 & $14.8 \pm 2.0$ \\
& 0.1 & $10.3 \pm 2.9(\mathrm{P}<.7)$ \\
& 0.2 & $8.4 \pm 2.7(\mathrm{P}<.2)$ \\
& 0.3 & $7.3 \pm 2.2(\mathrm{P}<.02)$
\end{tabular}

$\mathrm{EtOH}(\mathrm{v} / \mathrm{v})$ was added directly to a mixture of effector cells plus target cells and the NK activity was measured against prelabeled K562 target cells. Values represent mean $\%$ cytotoxicity \pm SD of triplicate determinations from 13 experiments using 13 different cord blood and 13 different adult peripheral blood lymphocyte samples. The NK aclivity was measured at 25:1 E:T cell ratio. Statistical significance of differences in the mean values was determined by two tailed student "t" test.

Table 2

Effect of Direct Addition of Cortisol on

NK Activity of Lymphocytes

\begin{tabular}{ccc}
\hline Effector Cell Source & $\begin{array}{c}\text { Concentration of } \\
\text { Cortisol (ug/ml) }\end{array}$ & \% Cytotoxicity \\
\hline \multirow{3}{*}{ aPBL } & & \\
& 0 & $25.7 \pm 4.8$ \\
& 0.05 & $24.3 \pm 2.9(\mathrm{NS})$ \\
& 0.1 & $21.4 \pm 3.7(\mathrm{NS})$ \\
& 0.2 & $22.7 \pm 2.9(\mathrm{NS})$ \\
& & \\
CBL & 0 & $14.8 \pm 2.0$ \\
& 0.05 & $8.5 \pm 2.6(\mathrm{P}<.05)$ \\
& 0.1 & $6.6 \pm 2.5(\mathrm{P}<.01)$ \\
& 0.2 & $6.5 \pm 2.0 \quad(\mathrm{P}<.005)$
\end{tabular}

Cortisol (ug/ml) was added directly to a mixture of effector cells plus target cells and the NK activity was measured against prelabeled K562 target cells. Values represent mean \% cytotoxicity \pm SD of triplicate determinations from 13 experiments using 13 diflerent cord blood and 13 different adult peripheral blood lymphocyle samples. The NK activity was measured at $25: 1 \mathrm{E:T}$ cell ratio. Statistical significance of differences in the mean values was determined by two tailed student " $t$ " test. 
Previously the authors have reported that CBL show significantly lower NK, ADCC and target binding activities compared to adult PBL (Nair et al, 1985). We also showed that patients with a history of intravenous drug abuse, often associated with excessive alcohol consumption, demonstrated decreased levels of NK, ADCC, interferon and interleukin-2 induced NK activities. (Nair et al, 1986) Further, we showed that lymphocytes from adult healthy subjects, pre-cultured in vitro with varying concentrations of alcohol corresponding to in vivo intoxicating levels manifested decreased levels of $\mathrm{NK}$ and ADCC activities; whereas direct addition of alcohol did not produce any significant suppression of NK activity (Nair et al 1990). The authors (Nair and Schwartz, 1984) and others (Callewaert et al, 1991) have shown that corticosteroids manifested significant inhibitory effects on NK activity of normal adult lymphocytes. However, the effect of alcohol and cortisol on NK activity of neonatal lymphocytes has not been clearly elucidated. The present investigation shows that alcohol and cortisol demonstrate a selective inhibitory effect on NK activity of CBL as compared to a-PBL. Direct addition of cortisol (equivalent to plasma levels in depressed patients) or alcohol (similar to in vivo intoxicating levels in human) to the mixture of aPBL and target cells did not produce any significant effect on the NK activity. However similar concentratons of alcohol and cortisol manifested significant inhibition of NK activity of CBL. The suppression caused by either cortisol or alcohol is not due to toxicity because the viability of treated $\mathrm{CBL}$ was comparable to that of control cultures (data not presented). Suppression caused by cortisol or alcohol on NK activity of CBL is also not due to selective effect on target cells because in control experiment K562 target cells preincubated with cortisol or alcohol for $4 \mathrm{hr}$ demonstrated similar levels of susceptibility to lysis (13.9\% cytotoxicity at $25: 1$ E:T cell ratio) by fresh effector cells as untreated target cells (14.2\%). Further, the spontaneous release of $51 \mathrm{Cr}$ from the target cells treated with alcohol or cortisol was less than 5\% of total labeling and was comparable to the spontaneous release from untreated target cells. The inhibitory effect of cortisol on NK activity of CBL was demonstrable at concentration as low as 0.05 and $0.1 \mathrm{ug} / \mathrm{ml}$, levels lower than the blood concentrations seen in depressed patients. In human, reports on the ontogeny of NK cells are conflicting (Rosenberg et al, 1972; Saksela et al, 1979; Abo et al, 1982). Defects in the ability of neonates to mediate NK activity against tumor and virus infected targets have been described by several investigators (Nair et al, 1985; Slukin and Chernishov, 1992).

Recently, Gasparoni et al (1991) showed a significantly high level of blood cortisol in infants born by vaginal delivery. The presence of high levels of cortisol in the blood of neonates born by vaginal delivery (Gasparoni et al, 1991) may corroborate with our finding of lower level of NK activity seen in neonates born by vaginal delivery and possible role for cortisol on NK suppression. However a previous study (Frazier et al, 1982) reported that lymphocytes from babies delivered by C-section without labor 
demonstrated significantly lower levels of NK and ADCC activities against Herpes Simplex Virus (HSV) infected Chang liver cells than that of babies delivered vaginally. This study did not (Frazier et al 1982) suggest a negative effect of cortisol on NK activity, since cortisol levels were reported to be lower in neonates delivered by Csection. It is possible that the depressed levels of NK activity as reported in their studies (Frazier et al, 1982) could have been due to the general anesthesia given for the C-section. However, the results presented herein provides direct evidence of selective inhibitory effects of cortisol on NK activity of CBL compared to no such effect observed on a-PBL with similar levels of cortisol. The elucidation of molecular mechanisms underlying alcohol or cortisol induced NK suppression may subsequently yield information applicable for the prevention or control of infections in neonates. Further, the synergistic role of alcohol and cortisol on NK activity remains to be studied.

\section{Conclusion}

This study shows a selective suppressive effect of alcohol (similar to in vivo intoxicating levels in humans) and cortisol (equivalent to plasma levels in depressed patients) on NK activities of lymphocytes from cord blood compared to that of adult peripheral blood lymphocytes, that may be of clinical significance.

\section{Acknowledgements}

The authors wish to express our sincere appreciation to Gerry Sobkowiak and Carol Sperry for their expert secretarial assistance. This work was supported in part by NIH grant No. 5lR01 42988, 2ROICA 35922, IROI MH 47225, IP50 AA 07378 and IP50MH 43564 .

\section{REFERENCES}

ABDALLAH, R.M. STARKEY, J.R. and MEADOWS, G. (1983) Alcohol and related dietary effects on mouse natural killer cell activity. Immunology 50: 131-137.

ABO, T. COOPER, M.D. and BALCH, C.M. (1982) Postnatal expansion of the natural killer and killer cell population in humans identified by the monoclonal HNK-1 antibody. J. Exp. Med. 155: 321-326.

ANTOVELLI, P. STEWART, II. W. and DUPONT, B. (1981) Distribution of natural killer cell activity in peripheral blood, cord blood, thymus, lymph nodes and spleen and the 
effect of in vitro treatment with interferon preparation. Clin Immunol Immunopathol. 19: 161-169.

BATEMAN, A. SINGH, A. KROL, T. and SOLOMON, S. (1989) The immune hypothalamicpituitary adrenal axis. Endocrine Rev. 10: 92-112.

BIONDI, M. and KOTZALIDIS, G. D. (1990) Human psychoneuroimmunology today. J. Clin. Lab. Anal. 4: 22-38.

BOYUM, A. (1968) Isolation of mononuclear cells and granulocytes from human blood: Isolation of mononuclear cells by one centrifugation and of granulocytes by combining centrifugation and sedimentation. J. Clin. Lab. Invest. Suppl. 97: 211-277.

CALLEWAERT, D.M. MOUDGIL, V.K. RADCLIFF, G. and WAITE, R. (1991) Hormone specific regulation of natural killer cells by cortisol. Direct inactivation of the cytotoxic function of cloned human NK cells without any effect on cellular proliferation. FEBS Letters 285:108-110.

CHANG, M. P. NORMAN, D. C. and MAKINODAN, T. (1990) Immunotoxicity of alcohol activities of $\mathrm{T}$ and $\mathrm{B}$ cells of aging mice. Alcoholism. 14: 210-215.

DELACROIX, D. L. ELKON, K.B. GENBEL, A.R. HEDGSON, H. F. DIVE, C. and VERMAN, J. F. (1982) Changes in size, subclass and metabolic properties of serum immunoglobulin A. Amer. J. Clin. Invest. 71: 358-367.

DOGGET, D. L. CHANG, M. P. MAKINODAN, T. and STREHLER, B. L. (1981) Cellular and molecular aspects of immune system aging. Mol. Cell Biochem. 37: 137-156.

DREW, P. A. CLIFTON, P. M. LABROOY, J. T. and SHEARMAN, D . J. C. (1984) Polyclonal Bcell activation in alcoholic patients with no evidence of liver dysfunction. Clin. Exp. Immunol. 51: 479-486.

DUNN, A.K. (1989) Psychoimmunology for the psychoneuroendocrinologist: A review of animal studies of nervous system-immune system interactions.

Psychoneuroendocrinology 4 : 251-274.

ERICSSON, C.D. KOHL, S. PICKERING, L. K. DAVIS, G. S. and FAILLACE, L. A. (1980) Mechanisms of host defense in well nourished patients with chronic alcoholism. Alcoholism 4: 261-265.

FAUCI, A. S. (1978) Mechanisms of the immunosuppressive and antiinflammatory effects of glucocorticoids. J. Immunopharmacol. 1: 1-11.

FRAZIER, J. P. KOHL, S. PICKERING, L. K. and LOO, L. S. (1982) The effect of route of delivery on neonatal natural killer cytotoxicity and antibody-dependent cellular cytotoxicity to herpes simplex virus infected cells. Pediatric Res. 16: 558-560.

GASPARONTITT, CHIRICO G, DEAMICI, D. MARCONI, M. BELLONI, C. MIAGRAT, G. and 
RINDINI, G. (1991) Neutrophil chemotaxis in infants delivered by Caesarean section. Eur. J. Ped. 50: 481-482.

GLASER, R. J. and KIECOLT-GLASE. (1987) Stress associated depression in cellular immunity. Implications for Acquired Immune Deficiency Syndrome (AIDS). Brain, Behavior, and Immun. 1:107-112.

GOTTESFELD, Z. CHRISTIE, R. FELTEN, D. L. and LEGRUE, S.J. (1990) Prenatal ethanol exposure alters immune capacity and noradrenergic synaptic transmission in lymphoid organs of the adult mouse. Neuroscience. 22: 715-723.

HASHIMOTO, G. WRIGHT, P. F. and KARZON, D.T. (1983) Ability of human cord blood lymphocytes to mediate antibody-dependent cellular cytotoxicity against anfluenza virus-infected cells. Infect. Immun. $\underline{42}$ : 214-218.

HERBERMAN, R.B. and HOLDEN, J. (1978) Natural cell mediated immunity Adv. Cancer Res. 27: 305-377.

HODGSON, H.J.K. WANDS, J.R. and ISSELBAEBER, K. J. (1978) Alteration in suppressor cell activity in chronic active hepatitis. Proc. Natl. Acad. Sci. USA. 75: 1549-1553.

JERRELLS, T.R. PERITT, A. MARIETTA, C. and ECKARDT, M.J. (1989) Mechanisms of suppression of cellular immunity induced by ethanol. Alcoholism 13: 490-493.

KAPLAN, J. SHOPE, T. C. BOLLINGER, R.O. and SMITH, J. (1982) Human newbornes are deficient in natural killer activity J. Clin. Immunol. 2: 350-355.

KAWANISHI, H. TAVASSOLI, H. MACDERMOTT, R.P. and SHEAGREN, J.N. (1981) Impaired concanacalin-A inducible suppressor $\mathrm{T}$ cell activity in active alcoholic disease. Gastroenterology. 80: 510-517.

KOHL, S, FRAZIER, J. P. PICKERING, L. K. and LOO, L. S. (1981) Normal function of neonatal polymorphonuclear leukocytes in antibody-dependent cellular cytotoxicity to herpes simplex virus-infected cells. J. Pediatr. $\underline{98:} 783-785$.

KRONFOL, Z. NAIR, M.P.N. GOODSON, J. AUEL, K. HASKETT, SCHWARTZ, S. A. (1990) Natural Killer cell activity in depressive illness, a preliminary report. Biological Psychiatry. 26: 753-756.

MAKINODAN, T. LUBINSKI, J. and FONG, T.C. (1987) Cellular biochemical and molecular basis of T-cell senescence. Arch. Pathol. Lab. Med. 111: 910-914.

MCKEEVER Y, MAHONEY CO, WHELAN CA, WEIR DG and FEIGHERY C: (1988) Helper and suppressor $T$ lymphocyte function in severe alcoholic liver disease. Clin. Exp. Immunol. 60: $39-48$.

MEADOWS, G.G. WALLENDAL, W. KOSNGI, A. WEINDERLICH, J. and SINGER, D.S. (1992) 
Ethanol induced marked changes in lymphocyte population and natural killer cell activity in mice. Alcoholism 16: 474-479.

MEADOWS, G.G. BLANK, S.E. and DUNCAD, D. D. (1989) Influence of ethanol consumption on natural killer cell activity in mice. Alcoholism. 13: 476-479.

MILlER, R.A. (1991) Aging and immune function. Internat. Rev. Cytology 124: 187215.

MORGAN, M. Y. ROSS, M. G. NG, C.M. ADAMS, D.M. THOMAS , H. C. and SHERLOCK, S. (1980) HLA-B8, immunoglobulins and antibody response in alcohol related liver disease. J. Clin. Path. 33: 488-492.

NAIR, M.P.N. and SCHWARTZ, S.A. (1983) Effect of histamine and histamine antagonists on natural and antibody dependent cellular cytotoxicity of human lymphocytes in vitro. Cell. Immunol. 81: 45-60.

NAIR, M.P.N. and SCHWARTZ, S.A. (1984) Immunoregulatory effects of corticosteroids on natural killer and antibody dependent cellular cytotoxic activities of human lymphocytes. J. Immunol. 132: 2876-2882.

NAIR, M.P.N. SCHWARTZ, S.A. and MENON, M. (1985) Association of decreased natural and antibody dependent cellular cytotoxicity and production of natural killer cytotoxic factor and interferon in neonates. Cell. Immun. 94: 159-171.

NAIR, M.P.N. LAING, T.J. and SCHWARTZ, S.S. (1986) Decreased natural and antibodydependent cellular cytotoxic activities in intravenous drug abusers. Clin. Immunol. Immunopath. 38: 68-78.

NAIR, M.P.N. and SCHWARTZ, S.A. (1988) Immunoregulation of human natural killer cells by corticosteroids. Inhibitory effects of culture supernatants. J. Allergy Clin. Immunol. $\underline{82}$ : 1089-1098.

NAIR, M.P.N. KRONFOL, Z.A. and SCHWARTZ, S.A. (1990) Effects of alcohol and nicotine on cytotoxic functions of human lymphocytes. Clin. Immunol and Immunopathology. 54: 395-409.

NAIR, M.P.N. SCHWARTZ, S.A. KRONFOL, Z.A. AND GREDEN, J.F. (1993) Suppression of tumor necrosis factor by alcohol in LPS stimulated human whole blood. Alcoholism: 16: 408 .

REDEI, E. BRANCH, B.J. GHOLAMI, S. LIN, E.Y. and TAYLOR, A. N. (1988) Effect of ethanol on CRF release in vitro. Endocrinology. 123: 276-2741.

REDEI, E. BRANCH, B. J. and TAYLOR, A.N. (1986) Direct effect of cthanol on adrenocorticotropin $(\mathrm{ACTH})$ release in vitro. J. Pharmacol. Exp. Ther. 237: 59-64. 
RILEY, V. (1981) Psychoneuroendocrine influences on immunocompetence and neoplasia. Science 214: 1104-1109.

ROSENBERG, E.B. HERBERMAN, R.B. LEVINE, P. H. HALTERMAN, R. H MCCOY, J. L. and WUNDERLICH, J. R. (1972) Lymphocyte cytotoxicity reactions to leukemia-associated antigens in identical twins. Int. J. Cancer 2 : 648-658.

SAAD, A.J. and JERRELLS, T.R. (1990) Flow cytometry and immunohistochemical evaluation of ethanol-induced changes in splenic and thymic lymphoid cell populations. Alcoholism 15: 796-803.

SAKSELA, E. TIMONEN, T. and CANTELL, K. (1979) Human natural killer cell activity is augmented by interferon via recruitment of 'pre-NK' cell. Scand. J. Immunol. 10: 257266.

SAXENA, Q.B. NEZEY, E. and ADLER, W.H: (1980) Regulation of natural killer activity in vivo. II. The effect of alcohol consumption on human peripheral blood natural killer cell activity. Int. J. Cancer. 26: 413-417 Saunders, Philadelphia.

SOLOMON GF: (1985) The emerging field of pychoneuro-immunology. SCHAFFER, A.J. and AVERY, M.E. (1971) Discases of the newborn p. 633. Advances 2: 7-19.

SLUKVIN, II. and CHERNISHOV, V.P. (1992) Two-color flow cytometric analysis of natural killer kland cytotoxic T-lymphocyte subsets in peripheral blood of normal human neonates. Biology of Neonate 61: 156-161.

STEIN, M. KELLER, S.E. and SCHLEIFER, S.J. (1988) Immune system: Relationship to anxiety disorders. Psyciatric Clin. North America, 11:360-369.

TARKKANEN, J. and SAKSELA, E. (1982) Umbilical-cord-blood-derived suppressor cells of the human natural killer cell activity are inhibited by interferon. Scand. J. Immunol. 15: $149-157$.

UKSILA, J. LASSILA, O. and HIRVONEN, T. (1982) Natural killer cell function of human neonatal lymphocytes. Clin. Exp. Immunol. 48: 649-654.

WAHL, S. M. ALTMAN, L.C. and ROSENSTRICH, D.L. (1975) Inhibition of invitro lymphokine synthesis by glucocorticosteroids. J. Immun. 115: 476-481.

WATSON, R.R. ESKELSON, C. and HARTMAN, B.R. (1984) Severe alcohol abuse and cellular immune functions. Arizona Med. 10: 665-668.

WELSH, R.M. (1980) Natural cell-mediated immunity during viral infections. Current Topics Microbiol. Immunol. 92: 83-106.

WU, W. PAHLAVANI, M. CHEUNG, H.T. and RICHARDSON, A. (1986) The effect of aging on the expression of interleukin 2 messenger ribonucleic acid. Cell. Immunol. 100: $224-231$. 
Alcohol and cortisol effects on cord blood NK cells

Human lymphocyte subpopulations. Effects of cortico-steroids. J. Clin. Invest. 53: 565571.

ZETTERMAN, R.K. and WOLTJEN, J.A. (1980) Suppressor cell activity in primary biliary cirrhosis. Dig. Dis. Sci. 25:(2) 104-107.

Inquiries and reprint requests should be addressed to:

Madhavan P.N. Nair, Ph.D.

Allergy/Immunology Division

Buffalo General Hospital

100 High Street

Buffalo, New York 14203 USA 